Türk Coğrafya Dergisi
Sayı 64: 11-18, istanbul
http://www.tcd.org.tr

\title{
Hakemli Makale
}

Reviwed Article

\section{Organize sanayi yatırımlarının mekânsal gelişim süreçlerine etkileri:Tuzla (İstanbul) örneği}

\author{
The effects of the organized industrial investments on the spatial development process: case \\ study of Tuzla (Istanbul)
}

Koray ÖZCAN ${ }^{a}$, Refik GÜNDOĞAR ${ }^{b}$

a) Pamukkale Üniversitesi, Mimarlık ve Tasarım Fakültesi, Şehir ve Bölge Planlama Bölümü.

b) Tuzla Belediyesi.
Geliş/Received: 03.12.2014 Kabul /Accepted: 15.01.2015

Sorumlu yazar/Corresponding author (K.ÖZCAN) korayozcan@pau.edu.tr

\section{Öz}

Bu araştırmanın amacı; Türkiye sanayisinin ana merkezi niteliğindeki İstanbul Metropoliten Alanı doğu çeperinde yer alan Tuzla yerleşmesinin mekânsal ve işlevsel gelişim-değişim sürecinde organize sanayi yatırımlarının etkilerinin araştırılmasıdır. Araştırmanın yöntem kurgusu, Tuzla yerleşmesinin sosyo-mekânsal ve işlevsel gelişimdeğişim sürecinin yazılı kaynaklar (tez, kitap, dergi, makale vb.), istatistiki veriler ile çiziligörsel kaynaklar (imar planları, raporları ve hava fotoğrafları) eşliğinde ayrıntıda değerlendirilmesine dayanmaktadır. Araştırmada, organize sanayi yatıımlarının kentsel yerleşmelerin mekânsal gelişim süreçlerinde sosyo-ekonomik çekim merkezi olarak önemli bir rol oynadığı, bu niteliği ile kentsel yerleşmelerin mekânsal ve işlevsel kimliğini biçimlendirdiği vurgulanmıştır. Bu araştırmanın, özellikle organize sanayi yatırımları gibi uzmanlaşmış planlı sanayi bölgelerinin, kentsel yerleşmelerin mekânsal ve işlevsel gelişim süreçleri üzerindeki etkilerinin öngörülmesine katkı sağlayacağı, yanısıra sanayi kentlerinin maruz kalabileceği mekânsal ve işlevsel sorunların çözümlenmesine yönelik tarihsel arka plana dayalı bir analitik çerçeve sunacağı düşünülmektedir.

Anahtar Kelimeler: Sanayileşme, kentleşme, mekânsal gelişme süreci, organize sanayi bölgeleri, Tuzla.

\section{ABSTRACT}

This study aims to examine the effects of organized industrial investments on spatial and functional development-changing process of Tuzla settlement located at the eastern hinterland of Istanbul Metropolitan Area. Methodologically, this study are based on the detailed evaluation of the written sources (thesis, book, paper and report), statistical data and also the visual sources (satellite maps, development plans and their reports) for defining of the socio-spatial and functional development-changing process of the Tuzla settlement. In the study, it is emphasized the organized industrial zones as an socioeconomic nucleus plays an important role for urban development process, and also shapes the spatial and functional identities of urban settlements. It is considered that this study contributes to the prediction of the effects of the organized industrial investments as the specialized planned industrial zones on the spatial and functional developmentchanging process of urban settlements. In that vein, this study attempts to present an analytical framework depending on historical context for solving the socio-spatial and functional problems of industrial settlements.

Keywords: Industrialization, urbanization, spatial development process, organized industrial zone, Tuzla.

\section{GiRiş}

Türkiye'nin hizmet ve sanayi sektöründeki odak noktası niteliğindeki İstanbul'un metropolitenleşme sürecinde, özellikle 1980 sonrası liberal ekonomi politikalarına koşut gerçekleşen mekânsal değişim-dönüşüm sürecinin sanayi sektöründeki yansımaları İstanbul metropoliten kent merkezinin hizmet sektörü odaklı yeniden işlevlendirilmesi ve sanayi yatırımlarının merkez dışına ötelenerek, ana ulaşım koridorları boyunca yeniden örgütlenmesi biçiminde olmuştur (Kılınçaslan 1981; Tekeli, 1994).

Sanayi yatırımlarının organize sanayi bölgeleri biçiminde İstanbul çeperinde yeniden örgütlenmesi, sanayileşmekentleşme etkileşimi bağlamında hızı kentsel gelişme- 
değişmelerin yaşanmasına neden olmuştur. Bu çerçevede, konumlandırıldıkları bölge ve yakın çevresi için sosyoekonomik çekim merkezi niteliğindeki organize sanayi bölgelerinin, sundukları istihdam potansiyelleri ile bulundukları çevredeki yerleşmelerin demografik ve mekânsal gelişim süreçlerini etkilediği söylenebilir.

$\mathrm{Bu}$ araştırmanın amacı; Türkiye sanayisinin ana merkezi niteliğindeki İstanbul Metropoliten Alanı doğu çeperindeki Tuzla yerleşmesinin mekânsal ve işlevsel gelişim-değişim sürecinde organize sanayi yatırımlarının etkilerinin tarihsel süreç eşliğinde araştırılmasıdır. Başka bir ifadeyle, İstanbul'un sayfiye-yazlık beldesi niteliğindeki Tuzla yerleşmesinin özellikle otonom kararlara dayanan organize sanayi bölgeleri odaklı yatırımlar ile sanayileşmesi sürecinin mekânsal karakteristik ve işlevsel kimlik üzerinde ortaya çıkardığı değişim-dönüşümlerin irdelenmesidir ${ }^{1}$.

Araştırma, Tuzla yerleşmesinin sosyo-mekânsal ve işlevsel gelişim-değişim sürecinin, yazılı kaynaklar (tez, kitap, dergi, makale vb.), istatistiki veriler ve imar planlarıraporları ile hava fotoğrafları gibi çizili-görsel kaynaklar eşliğinde ayrıntıda değerlendirilmesine dayanan bir yöntem kurgusu içinde ele alınmıştır. Bu kapsamda elde edilen veriler, harita ve şemalar üzerine aktarılarak mekânsal ve işlevsel gelişim-değişim sürecinin aşamaları tarihsel dizin ve kırılma noktaları bağlamında yorumlanmıştır.

$\mathrm{Bu}$ araştırmanın, özellikle organize sanayi yatırımları gibi uzmanlaşmış planlı sanayi bölgelerinin, kentsel yerleşmelerin mekânsal ve işlevsel gelişim süreçleri üzerindeki etkilerinin öngörülmesine katkı sağlayacağı, yanısıra sanayi kentlerinin maruz kalabileceği mekânsal ve işlevsel sorunların çözümlenmesine yönelik tarihsel arka plana dayalı bir analitik çerçeve sunacağı düşünülmektedir.

\section{KONU ve KAPSAM}

$\mathrm{Bu}$ araştırmanın konusu İstanbul Metropoliten Alanının doğu sınırını oluşturan 2013 yılı Adrese Dayalı Nüfus Kayıt Sistemi (ADNKS) verilerine göre yaklaşık 208.807 nüfusa sahip Tuzla yerleşmesidir. Tuzla yerleşmesi idari komşuluklar açısından; kuzey ve batı yönünde Pendik (İstanbul) İlçesi, doğu yönünde Darıca (Kocaeli) ve Çayırova (Kocaeli) ilçeleri ile Gebze İlçesi (Kocaeli), güneyde ise Marmara Denizi ile sınırlanmaktadır (Şekil 1).

Bu idari sınır ve komşuluklar kapsamında, Tuzla yerleşmesinin mekânsal karakteristik ve işlevsel gelişim-değişim süreci açısından kuzey-güney yönünde üç farklı yerleşim deseni gösterdiğini söylemek mümkündür.

Birinci bölge; Tuzla yerleşmesinin ilk kuruluş yeri olarak bilinen Tuzla Burnu odak olmak üzere doğu-batı yönünde uzanan kıyı hattı ile kuzeyde E-5 Devlet Karayolu ve İstanbul-Kocaeli Demiryolu güzergâhının sınırladığı yazlık-

$1 \mathrm{Bu}$ araştırma; ikinci yazarın birinci yazar danışmanlığında Selçuk Üniversitesi Fen Bilimleri Enstitüsü Şehir ve Bölge Planlama Anabilim Dalında 2013 yılında tamamlandığı “Organize Sanayi Yatırımlarının Mekânsal Gelişim Süreçlerine Etkileri Üzerine Bir Analiz: Tuzla (İstanbul) Örneği” başlıklı yüksek lisans tez çalışması temel alınarak kurgulanmıştır. mevsimlik konutlar ile kooperatif eliyle yapılandırılmış konut alanlarının bulunduğu bölgedir.

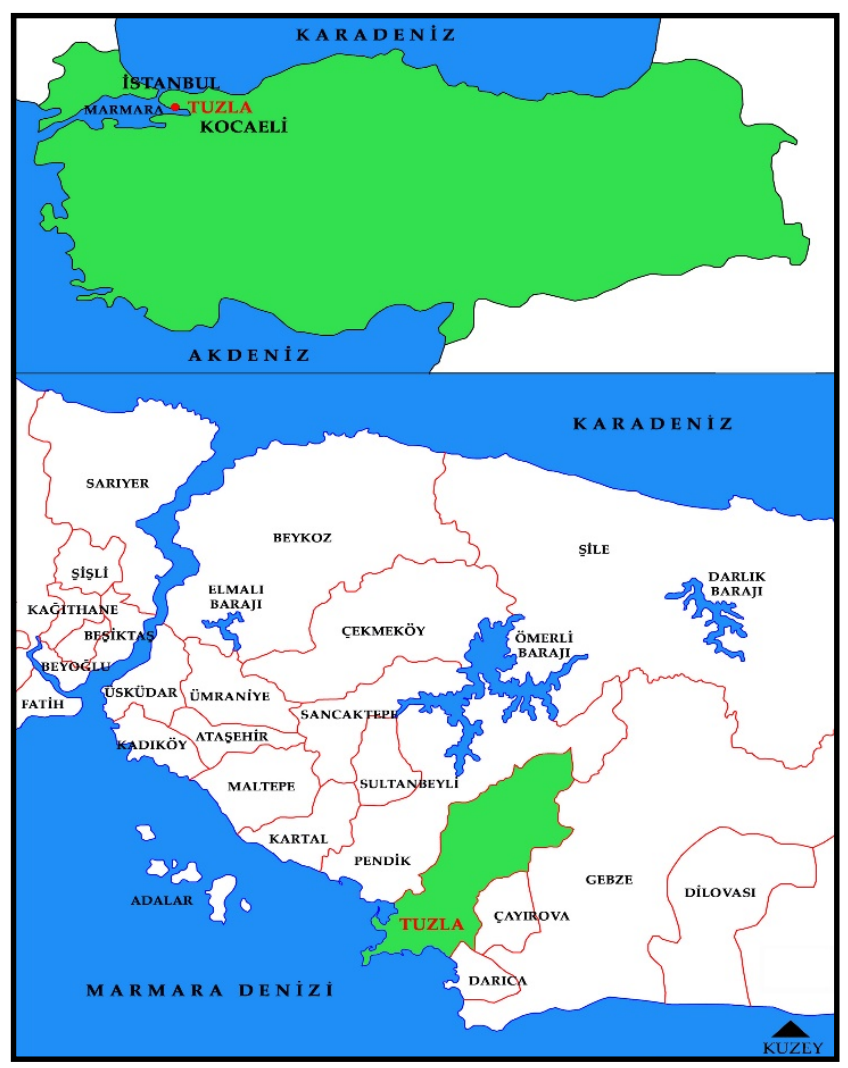

Şekil 1. Tuzla yerleşmesinin konumsal durumu.

Figure 1. The Location of Tuzla (Istanbul).

Kaynak: Istanbul Büyükşehir Belediyesi Ilçeler Haritası kullanılarak yeniden çizilmiştir.

Ikinci bölge; E-5 Devlet Karayolu ile kuzeyde TEM Otoyolu arasında uzanan organize sanayi bölgeleri ve yakın çevresinde plansız-denetimsiz inşaat yoluyla gelişen kaçak yapılaşma ve gecekondu alanları niteliğindeki konut alanlarından oluşan bölgedir.

Üçüncü bölge ise TEM Otoyolu ötesinde kuzeydeki Ömerli Su Havzası ile sınırlanan Sabancı ve Okan Üniversiteleri ile Formula 1 gibi uluslararası etkinliklere yönelik yatırımlar ile prestij konut projeleri eşliğinde kırsal karakterden kentsel karaktere geçiş sürecindeki Akfırat ve Tepeören beldelerinin bulunduğu bölgedir (Şekil 2).

Tuzla yerleşmesi jeomorfolojik açıdan incelenirse; güneyde Marmara Denizi kıyılarından kuzeyde Karatepe ve Kavastepe sırtlarına doğru ortalama \%9-16 arası eğim ile deniz seviyesinden 200 metreye dek yükselen bir topografyaya sahip olduğu, kıyılarda alüvyon, devamında ise Tuzla Formasyonu olarak adlandırılan gri masif kireçtaşı tabakalarından oluşan bir jeolojik yapı gösterdiği anlaşılmaktadır (Anonim, 1995; Kurtuluş vd., 2008).

İklimsel yapı ve bitki örtüsü açısından ise yazlar sıcak ve kurak, kışlar ise yağışlı olmak üzere Akdeniz-Karadeniz İklim Kuşakları arasında geçiş iklimi niteliğindeki Marmara iklimi etkisinde olduğu, Akdeniz bitki topluluğu olarak adlandırılan maki türü bitkiler ağırlıklı bir flora gösterdiği söylenebilir. Yıllık ortalama sıcaklık değeri $15 C^{0}$, yağış mik- 
tarı $720 \mathrm{~mm}$ ve nem oranı \%72 olarak kaydedilirken, hâkim rüzgâr yönleri ise kuzeydoğu yönünde Poyraz ve güneybatı yönünde Lodos olarak tespit edilmiştir (Özdemir, 2011).

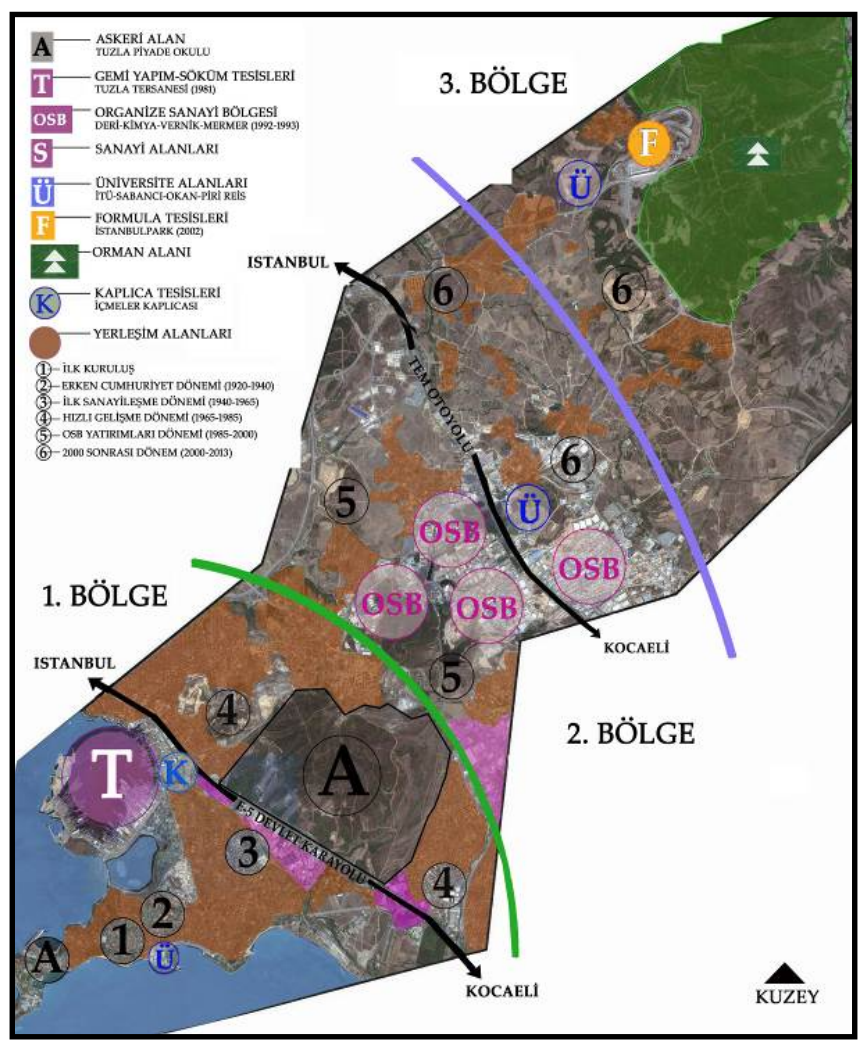

Şekil 2. Tuzla Yerleşmesinin Mekânsal ve İşlevsel Bölgelemesi. Figure 2. The spatial and functional zoning of Tuzla (Istanbul). Kaynak: Tuzla Belediyesi 2013 tarihli uydu fotoğrafı kullanılarak hazırlanmıştır.

\section{MEKÂNSAL ve IŞLEVSEL GELIŞiM SÜRECi}

Bu mekânsal-işlevsel bölgeleme kapsamında, sanayi yatırımlarının tetiklediği kentleşme-sanayileşme olguları eşliğinde gerçekleşen sosyal-kültürel ve ekonomik gelişmelerin, Tuzla yerleşmesinin mekânsal ve işlevsel gelişimi-değişim süreci üzerindeki etkileri zaman dizinsel bağlamda beş aşamadan oluşan bir süreçte ele alınmıştır.

\section{[1] ilk Kuruluş Dönemi (Roma-Bizans-Osmanlı)}

Arkeolojik araştırma bulgularına göre yerleşim kökeninin kalkolitik çağlara dek uzandığı anlaşılan Tuzla ve yakın çevresindeki ilk yerleşim sürecinin, bugünkü Tuzla-Kalekapı Mevki, Aydınlı Mahallesi-Hacet Deresi Mevki ile Temeyne Höyük-Kaynarca çevresinde başladığı söylenebilir ${ }^{2}$. Ancak, Roma-Bizans dönemlerine ilişkin tarihsel kayıtlar, süreç içinde yerleşim alanlarının bugünkü Tuzla burnunun bulunduğu bölgeye kaydığını düşündürmektedir. Nitekim Roma-Bizans dönemlerine tarihlendirilen Akritas yer adı,

\footnotetext{
2 Bu konuda bakınız: Kansu, Ş. A. (1972). "Yarımburgaz Küçükçekmeceİstanbul Mağarasında Türk Tarih Kurumu Adına Yapılan Prehistorya Araştırmaları ve Tuzla Kalkolitiğinde Yeni Gözlemler", VII. Türk Tarih Kongresi (25-29 Eylül 1970), 22-32, TTK Yayınları, Ankara.
}

Bizans döneminde korunaklı limana sahip bir balıkçı köyünün varlığına işaret etmektedir (Kuban, 1993).

Bu bilgiler, Tuzla ve yakın çevresinin Bizans başkenti Konstantinopolis (İstanbul) yakın komşuluğunda kırsal karakterli bir yerleşim yeri niteliğinde olduğunu ortaya koyması bakımından önemlidir. Bu niteliği ile özellikle Hıristiyanlığın yayılma sürecinde devlet teşvikleri altında gelişen manastır iskân yerleri için elverişli bir konuma sahip olduğu söylenebilir. Nitekim Tuzla burnu ve yakın çevresindeki adalarda bulunan arkeolojik-mimari kalıtlar, Bizans döneminde önemli bir manastır iskân yeri olabileceğini düşündürmektedir (Eyice, 1973; Soyhan, 1975; Koyunlu ve Atasoy, 1976).

Osmanlı dönemine ilişkin kaynaklarda, Sultan Çayırı ya da Tekfur Çayırı olarak adlandırılan Tuzla ve çevresinin, on altıncı yüzyılda Osmanlı askeri seferlerinde ordu konaklama yeri ya da menzil yeri olarak kaydedildiği görülür (Naîmâ, 1968: 1372/3, 1948/4; Matrakcı, 1976; Taeschner, 2010). Bu kayıtlara dayanılarak Tuzla ve yakın çevresinin kırsal karakterli bir bölge niteliğinde olduğunu söylemek mümkündür.

On yedinci yüzyıl başından itibaren Tuzla Burnu'nda Akritas olarak anılan Roma-Bizans dönemi yerleşim alanı yakınında (bugün Postane Mahallesi) inşa edilen Sultan Birinci Ahmet Camisi (1609) ve Davut Ağa Çeşmesi (1668) gibi anıtsal-kamusal hizmet yapı faaliyetleri, cami-çeşme odaklı küçük ölçekli bir yerleşim alanının çekirdeğini oluşturmuştur. Bugünkü Tuzla yerleşmesinin ilk kuruluş alanı olarak tanımlanabilecek bu çekirdek yerleşim alanı, kırsal karakterden kentsel karaktere geçişin ilk işareti olarak kabul edilebilir (Özdemir, 2011).

$\mathrm{Bu}$ tespitlerden; Tuzla ve yakın çevresinin on yedinci yüzyıldan itibaren mekânsal ve demografik açıdan cami inşa edilmesini gerektirecek oranda belirli ve sınırlı bir nüfus büyüklüğüne ulaştığı, buna dayalı olarak, birtakım ekonomik etkinliklerin gelişmesi ile tarımsal nitelikli art bölgesi için küçük ölçekli yerel pazar merkezi niteliği kazandığı söylenebilir.

On yedinci yüzyıl ikinci yarısına tarihlenen seyahat anlatılarında; Tuzla burnu kuzey batısında Roma-Bizans döneminden beri varolan içmeler adı verilen mevkideki şifalı su kaynaklarının varlığına dayalı olarak her sene Temmuz ayında düzenlenen şenliklerde, binlerce insanın toplandığı, çadırlar kurarak şifa bulmak için günlerce konakladığı kaydedilmektedir. Bu kayıtlar, Tuzla ve yakın çevresinin on yedinci yüzyılda sağlık hizmetlerine dayalı bilinirliktanınırlık açısından önemli bir çekim gücüne sahip olduğunu düşündürmektedir (Evliya Çelebi, 1999).

Osmanlı döneminde Tuzla ve yakın çevresinin mekânsal ve işlevsel gelişimine ilişkin son kayıtlar; on dokuzuncu yüzyıl sonunda ortaya çıkan kolera salgını için alınan önlemler kapsamında Tuzla burnunda inşa edilen tahaffuzhane (karantina yeri) tesisleri ile İstanbul-Bağdat 
Demiryolu Projesi kapsamında inşa edilen demiryolu hatt ve istasyon binası ${ }^{3}$ inşaatıdır (Ayar, 2005; Özdemir, 2011).

$\mathrm{Bu}$ değerlendirmeler eşliğinde; tarihsel kökenleri Bizans çağına dek uzanan kaplıcaların varlığı ile sağlık merkezi işlevi üstlenen Tuzla yerleşmesinin, Osmanlı döneminde önce askeri-stratejik açıdan konaklama ve menzil yeri işlevi kazandığı, Osmanlı son dönemlerinde inşa edilen tahaffuzhane tesisleri ile aynı zamanda sağlık denetim merkezi işlevi kazandığı söylenebilir.

\section{[2] Erken Cumhuriyet Dönemi (1920-1940)}

Tuzla ve yakın çevresinin özellikle 1924 Türk-Rum mübadelesi ile Yunanistan'dan gelen Türk nüfusun yerleştirilmesi sonucu gerek mekânsal ve işlevsel gerekse ekonomik ve demografik açıdan yeni ve farklı bir değişimgelişim sürecine girdiği söylenebilir (Aksel, 1994).

$\mathrm{Bu}$ çerçevede, mekânsal anlamda, Rum nüfusun boşalttığı binalara mübadele ile gelen Türk nüfus yerleşirken, sosyal-ekonomik anlamda ise ağırlıklı olarak zanaat-ticaret faaliyetleri ile uğraşan Rum nüfusun yerini ise şüphesiz belirli bir süreç sonunda Türk nüfusun aldığı söylenebilir. Dolayısıyla, erken Cumhuriyet döneminde Tuzla ve yakın çevresini mübadele yerleşmesi olarak tanımlamak mümkündür.

1930 döneminden itibaren özellikle İstanbul'un hızlı gelişme sürecinde demiryolu güzergâhı yakın çevresinde bugün İstasyon Mahallesi olarak adlandırılan bölgede ağırlıklı olarak konut kooperatifleri yoluyla inşa edilen yazlık-mevsimlik konut alanlarının yapılaşmaya başladığ görülür. Bu gelişmeler ile 1936 yılında Belediye statüsü kazanan Tuzla yerleşmesinin, İstanbul çeperinde yazlık siteler ve kooperatifler ile kamu kurumlarına ait yazlık kamp-tatil sitelerinin konumladığı, demiryolu sistemi ile ulaşılabilirliği sağlanan yazlık sayfiye bölgesi işlevi kazandığını düşündürmektedir (Anıl, 2005).

Tuzla yerleşmesi ve yakın çevresinin bu mekânsal karakter ve işlevsel kimliğini, Türkiye'de büyük kentlere göç olgusunun başladığı 1940'ların başlarına- dek koruduğunu söylemek mümkündür.

\section{[3] Sanayileşme-Kentleşme dönemi (1940-1965)}

İkinci Dünya Savaşı ve sonrasına tarihlenen bu dönemde, özellikle 1950'lerden itibaren Türk ekonomisindeki yapısal değişmeler ile İstanbul, bir taraftan Türkiye'nin sanayi odağı durumuna gelirken, diğer taraftan da sanayileşme sürecine koşut gerçekleşen göç olgusu eşliğinde metropolitenleşme sürecine girmiştir (Kılınçaslan 1981).

1955 tarihli Sanayi Bölge Planı kapsamında İstanbul kent merkezindeki küçük ve orta ölçekli sanayi alanlarının kent çeperlerine taşınması kararı ile sanayi alanlarının Tekirdağİstanbul-Kocaeli hattı boyunca uzanan ana ulaşım koridoru

\footnotetext{
${ }^{3}$ Bu konuda şu çalışmalara bakılabilir: Koçer, Ş. (1995). HaydarpaşaGebze Demiryolu Hattında 19. Yüzyılda Yapılmış Demiryolu Istasyon Binaları, İstanbul Teknik Üniversitesi Sosyal Bilimler Enstitüsü, İstanbul. Erkan, Y. K. (2007). Anadolu'da Demiryolu Çevresinde Gelişen Mimari ve Korunması, İstanbul Teknik Üniversitesi Fen Bilimleri Enstitüsü, İstanbul.
}

niteliğindeki E-5 Devlet Karayolu boyunca öbeklendiği görülür (Tekeli, 1994; Aysu, 1990). Sanayi Planı kapsamında Tuzla-Pendik bölgesi, büyük ölçekli sanayi alanları ile serbest ticaret bölgesi olarak belirlenmiştir (Tekeli, 1994).

Bu gelişim-değişim sürecinin Tuzla ve yakın çevresindeki yansımaları, Tuzla yerleşmesini doğu-batı yönünde kesen E-5 Devlet Karayolu boyunca Jeep Motorlu Araç Fabrikası (1954), Arçelik (1955) ve İstanbul Porselen Fabrikası (1962) gibi büyük ölçekli sanayi tesislerinin kurulması biçiminde olmuştur.

Sanayi yatırımlarının Tuzla yerleşmesinin nüfus ve kentleşme sürecindeki etkilerini nüfus istatistikleri üzerinden irdelemek mümkündür. Bu bağlamda 1950 yılında yaklaşık 3.063 nüfusa sahip iken, 1960 yılında 4.393, 1965 yılında ise yaklaşık iki kat artış göstererek 7.393 nüfusa ulaştığı görülür. Bu nüfus artış değerlerinin, İstanbul için yazlıksayfiye bölgesi niteliğindeki bir yerleşme için gerek mekânsal gerekse işlevsel etkiler açısından oldukça radikal bir gelişme olduğunu söylemek mümkündür. Nitekim sanayileşme sürecine koşut ivme kazanan nüfus hareketleri ve kentleşme talepleri, denetimsiz-plansız inşaat yoluyla gelişen ilk gecekondu ve kaçak yapılaşma alanlarını ortaya çıkarmıştır (Aksel, 1994).

Bu dönemin önemli gelişmelerinden bir diğeri ise Yedek Subay Hazırlama (Piyade) Okulu'nun (1961) Tuzla yerleşmesi kuzeyine taşınması kararıdır. Bu kamu yatırımı yer seçim kararının Tuzla yerleşmesinin sosyo-ekonomik ve mekânsal gelişim sürecinde etkili olduğu söylenebilir. Sosyo-ekonomik açıdan bakılırsa, Yedek Subay Hazırlama Okulu'nun özellikle ticarete dayalı hizmet sektöründeki gelişmeleri hızlandırdığını, mekânsal açıdan ise, Tuzla yerleşmesinin özellikle kuzey yönündeki gelişme alanlarını sınırlayıcı bir mekânsal öğe/yapay eşik niteliği kazandığı anlaşılmaktadır (Şekil 3).

\section{[4] Hızlı Gelişme Dönemi (1965-1985)}

Bu döneme ilişkin en önemli gelişme, 1973 yılında açılan Boğaziçi Köprüsü ve çevre yollarının İstanbul'un Anadolu yakası ile Avrupa yakası arasındaki erişilebilirliği arttırması, özellikle Anadolu yakasında Kadıköy-Kartal hattı boyunca uzanan bölgelerin gelişmeye ve yoğunlaşmaya başlaması olarak görülmektedir. Bu gelişmelerin Tuzla yerleşmesi ve yakın çevresindeki yansımalarının, sanayi sektörü ağırlıklı yatırım kararları ile sanayiye dayalı işgücünün barınma taleplerine dayalı mekânsal ve işlevsel gelişmeler biçiminde olduğunu söylemek mümkündür. Nitekim 1970-1980 dönemi nüfus istatistikleri irdelenirse; Tuzla yerleşmesinin 1970 yılında 9.905, 1975 yılında 11.163, 1980 yılında ise 16.440 nüfusa ulaştığı görülür. Nüfus gelişiminde gözlemlenen radikal artış, Tuzla yerleşmesinin hızlı sanayileşme-kentleşme sürecine koşut nüfus hareketlerinegöç olgusuna konu olduğunu göstermesi bakımından önemlidir.

Bu süreçte, Tuzla yerleşmesini doğu-batı yönünde kesen E-5 Devlet Karayolu ve paralelinde uzanan İstanbulKocaeli Demiryolu güzergâhı fiziki eşik olmak üzere gerek arazi kullanım deseni gerekse sosyo-mekânsal açıdan 
keskin farklılıklar gösteren iki alt bölgeye ayrıldığını söylemek mümkündür.

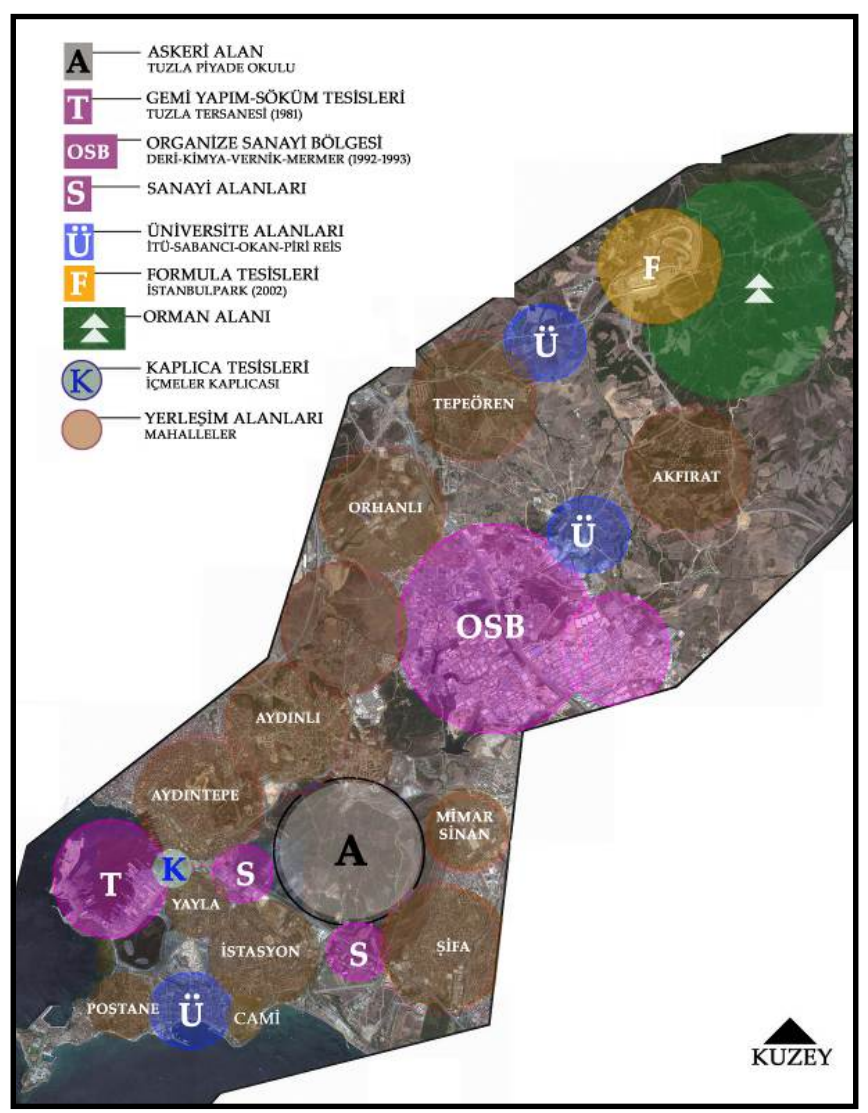

Şekil 3. Tuzla yerleşmesinde işlevsel kullanım alanlarının Dağılımı.

Figure 3. The distribution of the functional usages in Tuzla (istanbul).

Kaynak: Tuzla Belediyesi 2013 tarihli uydu fotoğrafı kullanılarak hazırlanmıştır.

Birinci bölge, Güzelyalı (1965), Yayla (1967) ve İstasyon (1972) Mahalleleri gibi konut kooperatifleri ve sanayi tesis lojmanları kurulması biçimde gelişmelerin gözlemlendiği Marmara Denizi kıyısındaki ilk kuruluş yeri ile E-5 Devlet Karayolu arasında kalan bölgedir. İkinci bölge ise; özellikle sanayi sektöründeki gelişmelere dayalı olarak ortaya çıkan istihdam olanaklarına koşut ortaya çıkan plansızdenetimsiz inşaatlar yoluyla biçimlenen E-5 Devlet Karayolu kuzeyinde uzanan bölgedir (Şekil 2 ve Şekil 3).

$\mathrm{Bu}$ iki bölgenin dışında, E-5 Karayolu çevresindeki sanayiye dayalı gelişen düşük-orta gelir grubuna yönelik konut alanları ile tezat oluşturacak biçimde, ilk kuruluş bölgesi niteliğindeki Postane Mahallesi olarak anılan kıyı bölgelerinin (Manastır ve Mercan mevkileri) dönemin mimarlık dergilerine de konu edilen yüksek gelir grubuna yönelik düşük yoğunluklu sayfiye konut projeleri ${ }^{4}$ yoluyla geliştiri-

${ }^{4}$ Kortan, E. (1967). "Yelkenci Villası", Arkitekt 1(325), 5-7. Sağlıkova, Y. (1979). "Tuzla-Mercan Yuvasında Villa", Arkitekt 3(375), 88-89. Arguvanlıgil, ì. ve Kaya, S. (1979). "Balıkçı Koyu Sitesi-Tuzla”, Arkitekt 3(375), 94. Uzman, N. (1980). "Tuzla'da Bir Yaz Evi", Arkitekt, 3(379), 8384. len Prestij Konut Bölgesinin (yazlık konut bölgesi) varlığından söz edilebilir.

Sosyo-mekânsal gelişim süreci açısından bakılırsa, Tuzla yerleşmesinin mekânsal ve işlevsel kimliği açısından iki önemli gelişmenin kırılma noktası olarak öne çıktığı görülmektedir:

Illk kırılma noktası, 1980'li yıllarda İstanbul metropoliten kent gelişim sürecinde Haliç Tersanesi yapısal tesislerinin İstanbul kent merkezinden (Haliç Bölgesi) taşınarak, TuzlaAydınlı koyunda yer seçmesidir. İkinci kırılma noktası ise, Tuzla yerleşim alanındaki sanayi kümelenmesinin tetiklediği plansız-denetimsiz gelişmeleri kontrol altına alabilmek için 1985 yılında hazırlanan Nazım İmar Planı olarak görülmektedir. Bu plan, Tuzla yerleşmesindeki mekânsal gelişmelerin denetim altına alınabilmesi ve planlı gelişme sağlanabilmesi için E-5 Devlet Karayolu ile Marmara Denizi arasında kalan bölge için hazırlanmış olup Tuzla yerleşmesinin ilk imar planı deneyimi olması açısından önemlidir.

Bu noktada şu tespit önemlidir: Tuzla Tersanesi yer seçimi kararı, Tuzla yerleşmesinin mekânsal ve işlevsel gelişiminin, İstanbul'un kentsel gelişim-değişim sürecinden bağımsız değerlendirilmemesi gereğine vurgu yapması bakımından önemlidir ${ }^{5}$. Nitekim gemi inşa yapım-söküm içerikli tersane yapısal tesislerinin Tuzla'da kurulması, tersane ve yakın çevresinde konut gelişim taleplerini hızlandırmıştır (Anıl 2005).

Bu süreçte, Tersane tesisleri yakın komşuluğunda Aydıntepe ve İçmeler mahalleleri hızla gelişirken, E-5 Devlet Karayolu kuzeyinde devam eden sanayi yatırımlarına koşut olarak Şifa ve Esenyalı mahalleleri, Tuzla yerleşmesinin mekânsal çerçevesine eklemlenmiştir (Şekil 2 ve Şekil 3).

Bu dönemde Tuzla yerleşmesinin idari statüsü açısından en önemli gelişme; Belediye Kanunu'nda yapılan değişiklik ile İstanbul'un Büyükşehir Belediyesi statüsü kapsamında yeniden yapılandırılması sürecinde, 1989 yılında köy statüsü altında Pendik İlçesi'ne bağlanması olarak görülmelidir.

\section{[5] Organize Sanayi Yatırımları Dönemi (1985-2013)}

Bu dönemde Tuzla yerleşmesinin mekânsal ve işlevsel gelişim sürecinde iki önemli olgunun etkin olduğu görülmektedir. Birincisi, Tuzla yerleşmesi yakın çevresinde yer seçmeye başlayan organize sanayi yatırım kararları, ikincisi ise üniversite yerleşkeleri ile büyük kamusal eğlence-spor yatırım kararları olarak söylenebilir. Bu iki gelişme eşliğinde Tuzla yerleşmesinin hızlı bir nüfus artışı sürecine girdiği söylenebilir. Bu bağlamda, Tuzla yerleşmesinin 1985 yılında 28.824 olan nüfusunun, 1990 yılında 96.150, 2000 yılında 123.225, 2010 yılında 185.819 ve 2013 yılında ise 208.807 nüfus büyüklüğüne ulaştığı anlaşılmaktadır.

\footnotetext{
5 Tuzla Tersaneleri yer seçimi tartışmaları için bakınız: Anonim (1971) "Planlama Örgütünden/Tuzla-Aydınlı Koyu Tersanesi Hakkında Mimarlar Odası Görüşü", Mimarlık 92, 42-43. Anonim (1971). "Tuzla Özel Sektör Tersanesi Yer Seçimi ve Projesi Kararının Belirsiz Yönleri”, Mimarlık 93, 43.
} 
1980'li yılların sonunda Fatih Sultan Mehmet Köprüsü ve TEM Otoyolunun hizmete girmesi (1988) ile erişilebilirlikulaşılabilirlik olanaklarının artması, 1990'lı yılların başından itibaren ise Zeytinburnu-Kazlıçeşme bölgesinde deri sanayi tesislerinin İstanbul Organize Deri Sanayi Bölgesine (1992) taşınması ile Tuzla ve yakın çevresindeki sanayi ve konut içerikli mekânsal gelişmeleri hızlandığı söylenebilir. Nitekim 1992-2002 arasında yaklaşık on yıllık süreçte Tuzla-Orhanlı bölgesinde sırasıyla İstanbul Endüstri ve Ticaret Serbest Bölgesi (1996), Mermerciler Organize Sanayi Bölgesi (1998), Tuzla Organize Sanayi Bölgesi (2000), Boya ve Vernik Organize Sanayi Bölgesi (2000) ile Kimya Sanayicileri Organize Sanayi Bölgesi (2001) kurulduğu görülür (Bilgin ve Ar, 2004; Doğan 2013).

Organize sanayi bölgelerinin varlığı, Tuzla yerleşmesinin İstanbul metropoliten alanı içinde mekânsal karakter ve işlevsel kimliğinin yeniden tanımlanmasında ya da mekânsal dönüşüm sürecinde belirleyici bir unsur olarak görülebilir. Nitekim özellikle 1992-2002 döneminde gerçekleştirilen yoğun sanayi yatırımlarına dayalı olarak, İstanbul metropoliten alanı doğu bölümünde sanayi ve sanayiye dayalı depolama-lojistik işlevler, Tuzla yerleşmesi çevresinde yoğunlaşmaya başlamıştır. Bu dönüşüm sürecinin idari statü kapsamındaki yansıması, Tuzla yerleşmesinin 1992 yılında İstanbul Büyükşehir Belediyesi'ne bağlı Merkez İlçe Belediyesi statüsü kapsamında örgütlenmesi biçiminde olmuştur. Mekânsal yansıması ise organize sanayi bölgelerinde istihdam edilen işgücünün konut gereksinimlerinin karşılanmasına yönelik plansız-denetimsiz inşaat yoluyla gelişen kaçak yapılaşma ve gecekondu bölgeleri olarak görülmelidir. Bu bağlamda, organize sanayi bölgeleri komşuluğundaki güneybatıda Aydınlı Köyü ile güneydoğuda Mimar Sinan ve Şifa Mahalleleri başta olmak üzere Tuzla yerleşmesi kuzeyindeki ikinci Bölge olarak tanımlanan yerleşim alanları gelişmeye başlamıştır (Anıl, 2005).

2000'li yılların başından itibaren -özellikle ilk on yıllık süreçte- kamu ve özel sektöre ait yükseköğretim ve ortaöğretim yerleşkeleri ${ }^{6}$ ile ulusal-uluslararası kamusal eğlencespor yatırımı İstanbul Park yarış pisti ve tesislerinin, Tuzla yerleşmesi kuzeyinde konumlandırılması, Üçüncü Bölge olarak tanımlanan kuzeydeki kırsal karakterli yerleşmelerde hızlı mekânsal değişim-dönüşümlere neden olduğu söylenebilir. Nitekim Tuzla yerleşmesi kuzeyindeki Orhanlı, Tepeören ve Akfırat köyleri, bir taraftan hızlı nüfus artışına koşut belediye statüsü kazanırken, diğer taraftan kamu ve özel girişim eliyle üretilen toplu konut projeleri yoluyla kentsel dönüşüm süreci hız kazanmıştır (Dönmez, 2009).

Tuzla yerleşmesindeki kentsel dönüşüm sürecinin iki farkIı nitelik gösterdiği söylenebilir. Birincisi, hızlı sanayileşmekentleşme döneminde oluşan E-5 Devlet Karayolu boyunca uzanan kaçak yapı-gecekondu alanlarının (Aydınlı, Mimar Sinan ve Şifa mahalleleri) kamu (TOKi-Belediye) ortaklığına dayanan projeler yoluyla yenilenmesine yönelik toplu konut projeleridir. Ikincisi ise, özellikle TEM Otoyolu kuzeyin-

6 Tuzla yerleşmesinde 2000 yılı sonrasında kurulan yükseköğretim kurumları arasında Sabancı (1999), Okan (2006), Süleymanşah (2008), Gedik (2010), Medeniyet (2010) üniversiteleri sayılabilir. deki Tepeören-Akfırat bölgelerinde ivme kazanan prestij konut projeleridir.

Bu noktada, toprak kullanım deseni ağırlıklı olarak tarım ve orman alanlarından oluşan Tepeören-Akfırat bölgesinde 2003-2010 döneminde yerleşim alanı oranlarının yaklaşık üç buçuk kat arttığına ilişkin araştırma bulguları, mekânsal gelişme sürecinin kapsam ve boyutlarını göstermesi bakımından dikkat çekicidir (Kandemir ve Ustaoğlu, 2011).

Tuzla yerleşmesi, -2013 yılı itibarıyla- il Çevre Düzeni Planı kapsamında İstanbul metropoliten alanı doğu çeperinde; Deri, Mermer, Kimya, Boya ve Vernik Organize Sanayi Bölgeleri gibi uzmanlaşmış sanayi yatırımları eşliğinde Üretim-Dağıtım ve Depolama-Lojistik faaliyetlere yönelik tesislerin öbekleneceği Alt Merkez işlevini yüklenmiştir (Anonim, 2009). Bu işlev kapsamında E-5 Devlet Karayolu ile TEM Otoyolu arasında kalan alanlar, Lojistik Bölgeler [L], Eğitim-Bilişim ve Teknoloji Geliştirme Alanları [EBT], Organize Sanayi Bölgeleri [OSB] ve İleri Teknoloji Bölgesi [ITA] olarak belirlenmiştir. E-5 Devlet Karayolu güneyinde kalan ilk yerleşim alanı niteliğindeki konut kullanım alanları ile kıyı şeridi arasında Rekreasyon Alanları olarak tanımlanırken, batı kıyı şeridi boyunca mevcut Gemi Yapım-Söküm Tesis Alanlarına [T] ek olarak, Tersane Gelişme Alanı $\left[T_{G}\right]$ ve Marina-Liman Tesis Alanları oluşturulmuştur (Şekil 4).

\section{SONUÇ}

Sanayileşme-kentleşme olgularını birbirine koşut olarak gerçekleşen ve karşılıklı etkileşim içinde olan süreçler olarak değerlendirmek mümkündür. $\mathrm{Bu}$ bağlamda, sanayi sektöründeki yapısal değişim-gelişimlerin ya da sanayi sektöründe organize sanayi bölgesi ya da lojistik merkezler gibi planlama kararlarına dayanan ölçek-kapsam değişikliğinin, kentsel yerleşmelerin özellikle fiziki çevre ya da mekânsal gelişim süreçleri üzerinde birtakım etkilerinin olabileceği kaçınılmaz bir olgu olarak görülmelidir.

Organize sanayi yatırımlarının Tuzla yerleşmesi örneğinde mekânsal gelişim sürecine etkilerini, tarihsel dizinde kırılma noktaları temel alınarak belirlemeyi hedefleyen bu araştırma sonunda, mekânsal ve işlevsel kimlik bağlamında tarımsal üretim odaklı köy yerleşmesi statüsünden, sanayilojistik odaklı ilçe merkezi statüsüne değişim-gelişim sürecinde organize sanayi yatırımlarının mekânsal etkilerine ilişkin birtakım sonuçlara ulaşılması mümkün olabilmiştir.

\section{Bu sonuçlar dört başlık altında değerlendirilebilir.}

Birincisi, 1992 yılında kurulan ilk organize sanayi bölgesi niteliğindeki deri sanayi bölgesi ile başlayan vernik, boya, kimya organize sanayi bölgelerinin kurulması ile devam eden sürecin, planlama kararları eşliğinde kapsam-ölçek ve nitelik bağlamında değişim-dönüşüm göstermesi ve uzmanlaşmasıdır. Organize Sanayi Bölgelerine dayalı işlevsel uzmanlaşmaya dayalı mekânsal öbeklenme, süreç içinde üst ölçekli plan kararlarına önemli girdi sağlamıştır. Bu bağlamda, depolama alanları, ileri teknoloji bölgeleri, lojistik merkezler ve havalimanı gibi üretim-dağıtım-aktarım zincirinde organize sanayi bölgeleri ile ilişkili işlev alanlarının Tuzla yerleşmesi yakın çevresinde yer seçmesinde, 


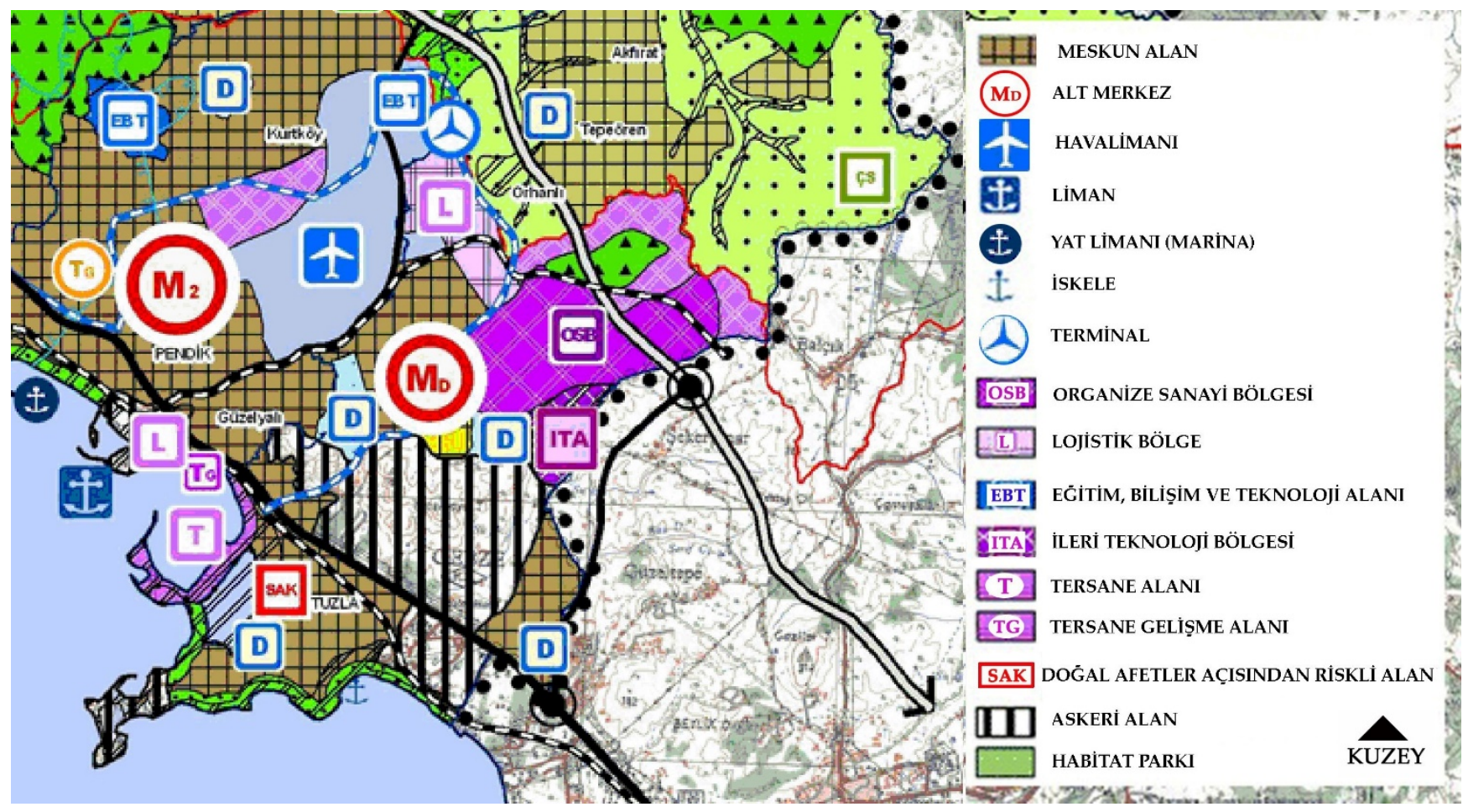

Şekil 4. İstanbul Çevre Düzeni Planında Tuzla yerleşmesi.

Figure 4. Tuzla (İstanbul) in Istanbul Province Environment Regulation Plan.

Kaynak: İstanbul Büyükşehir Belediyesi Arşivi.

sanayi sektöründeki uzmanlaşmanın getirdiği birikim ve deneyiminin etkili olduğudur.

İkincisi, sanayi alanlarının kurumsal bir çerçevede organize sanayi bölgeleri biçiminde planlı olarak geliştirilmesine karşılık, yakın çevresinin tamamen yasadışı-plansız ve denetimsiz konut alanları biçimde gelişmesidir. Mekânsal ve işlevsel açıdan birbirine tezat bu gelişme biçiminin; ancak belirli ve tanımlı bir süreç sonunda yerel ya da merkezi yönetimler eliyle üretilen toplu konut alanları üretilmesi yoluyla (kısmen) denetim altına alınabildiği söylenebilir.

Üçüncüsü, Tuzla yerleşmesi bütününde konut sunum ve üretim biçimlerinde sosyo-mekânsal bağlamda iki (2) farklı nitelikte değişim-dönüşüm olgusunun varolduğu belirlenmiştir. Buna göre, organize sanayi bölgeleri yakın çevresinde kümelenmiş plansız-denetimsiz inşaat yoluyla gelişmiş kaçak yapılaşma-gecekondu alanları, kamu ortaklığına (TOKI-Belediye) dayanan, düşük ve orta gelir grubuna yönelik toplu konut projeleri yoluyla kentsel dönüşüm sürecine konu edilirken, organize sanayi bölgeleri ötesindeki kırsal alanlar ise özel inşaat şirketleri eliyle üretilen üst gelir grubuna yönelik konut projeleri eşliğinde prestij-lüks konut alanlarına dönüşmektedir.

Dördüncüsü, Tuzla yerleşmesi kuzeyinde, TEM Otoyolu ötesindeki yer alan kırsal karakterli alanların, Sabancı ve Okan Üniversiteleri gibi yükseköğretim yerleşkeleri ile Formula 1 gibi uluslararası etkinliklere yönelik yatırımlar eşliğinde artan toprak değerlerine koşut olarak özellikle prestij konut projeleri eşliğinde gerek sosyo-mekânsal gerekse işlevsel açıdan hızla kentsel karaktere dönüşmesidir. Bu dönüşüm sürecinin karakteri, metropolitenleşme sürecinde sanayi ve hizmet sektörü odaklı gerçekleşen mekânsal ve işlevsel gelişme talepleri bağlamında değerlendirilmelidir.

Araştırma kapsamında Tuzla yerleşmesi örneğinde hızlı sanayileşme-kentleşme süreçlerine koşut gerçekleşmekle birlikte, süreç içinde üst ölçekli planlama kararları ile biçimlendirilen mekânsal ve işlevsel gelişim-değişim sürecinin arka planına ilişkin sonuçların, organize sanayi yatırımlarına konu olan yerleşmeler bağlamında gerek akademik-bilimsel gerekse uygulama düzeyindeki çalışmalara bilgi birikimi ve deneyim açısından katkı sağlayacağı düşünülmektedir.

\section{KAYNAKLAR}

Aksel, A. (1994). "Tuzla İlçesi", Dünden Bugüne İstanbul Ansiklopedisi, VII, 306-307, Türkiye Ekonomik ve Toplumsal Tarih Vakfı, İstanbul.

Anıl, A. (2005). Tuzla'nın Mekânsal Gelişimi, Basılmamış Yüksek Lisans Tezi, iü. Sosyal Bilimler Enstitüsü, İstanbul.

Anonim (2009). 1/100.000 Ölçekli Istanbul Çevre Düzeni Planı Raporu, İstanbul Büyükşehir Belediyesi İmar ve Şehircilik Daire Başkanlığı Şehir Planlama Müdürlüğü, İstanbul.

Anonim (1995). 1/50.000 Ölçekli Istanbul Metropoliten Alan Alt Bölge Nazım Imar Plan Raporu, İstanbul Büyükşehir Belediyesi İmar ve Şehircilik Daire Başkanlığı Şehir Planlama Müdürlüğü, İstanbul. 
Ayar, M. (2005). Osmanlı Devleti'nde kolera salgınıIstanbul örneği (1892-1895), Doktora Tezi, Marmara Üniversitesi Türkiyat Araştırmaları Enstitüsü, İstanbul.

Aysu, E. (1990). İstanbul Anakent Alanında Kentiçi Devingenlik Örüntüsü Üzerine Bir Deneme, Yıldız Üniversitesi Yayınları, İstanbul.

Bilgin, M.H. ve Ar, S. (2004). Istanbul Organize Sanayi Bölgeleri ve Siteleri, İstanbul Ticaret Odası, İstanbul.

Doğan, M. (2013). "Geçmişten günümüze İstanbul'da sanayileşme süreci ve son 10 yıllık gelişimi", Marmara Coğrafya Dergisi 27, 511-550.

Dönmez, F. (2009). Büyük Ölçekli Etkinliklerin Kente Girişi ve Neoliberalizmin Dönüşen Mekânları: Formula 1 ve Akfırat Örneği, Basılmış Yüksek Lisans Tezi, MSÜ, Fen Bilimleri Enstitüsü, İstanbul.

Evliya Çelebi. (1999). Evliya Çelebi Seyahatnamesi, Yapı Kredi Yayınları, İstanbul.

Eyice, S. (1973). “Tuzla'nın Değirmenaltı Mevkiinde Bir Bizans Kalıntısı", Sanat Tarihi Yıllığı, 5, 28-29.

Gündoğar, R. (2013). Organize Sanayi Yatırımlarının Mekânsal Gelişim Süreçlerine Etkileri Üzerine Bir Analiz: Tuzla (İstanbul) Örneği, Basılmamış Yüksek Lisans Tezi, Selçuk Üniversitesi Fen Bilimleri Enstitüsü, Konya.

Kandemir, N. ve Ustaoğlu, B. (2011). “Coğrafi bilgi sistemleri ve uydu görüntüleri ile Akfırat ve çevresinde (Tuzla-istanbul) 2003-2010 yılları arasında arazi örtüsü değişimlerinin belirlenmesi", SAÜ Fen Edebiyat Dergisi II, 163-183.

Kılınçaslan, i. (1981). Istanbul: Kentleşme Sürecinde Ekonomik ve Mekânsal Yapı ilişskileri, ITÜ Yayınları, İstanbul.

Koyunlu, A. ve Atasoy, S. (1976). "Tuzla civarındaki adalarda yapılan araştırmalar", iтÜ Mimarlık Fakültesi Mimarlık Tarihi ve Restorasyon Enstitüsü Bülteni, 2 (56), 58-60.

Kuban, D. (1993). "Akritas", Dünden Bugüne Istanbul Ansiklopedisi, I 160, Türkiye Ekonomik ve Toplumsal Tarih Vakfı, İstanbul.

Kurtulmuş, C., Bozkurt, A. ve Demirci, C.H. (2008). “Tuzla (İstanbul) illçesi'nde jeolojik, jeofizik ve jeoteknik yöntemler ile zemin özelliklerinin belirlenmesi", Uygulamalı Yerbilimleri Dergisi, 7(2), 10-30.

Matrakcı, Nasuhü's-Silahi. (1976). Beyan-ı Menazil-i Seferi Irakeyn-i Sultan Süleyman Han, Çev. Hüseyin G. Yurdaydın, Türk Tarih Kurumu Yayınları, Ankara.

Naima, Mustafa Efendi (1968). Naîmâ Tarihi, III-IV, Çev. Zuhuri Danışman, Zuhuri Danışman Yayınevi, İstanbul.

Özdemir, M. (2011). Tuzla Tarihi: Yeni Taş (Neolitik) Çağından 2011'e Kadar, Tuzla Belediyesi Yayınları, İstanbul.

Soyhan, C. (1975). "Tuzla Ekrem Bey adasındaki Bizans manastırı ve civarındaki kalıntılar", iтÜ Mimarlık Fakültesi Mimarlık Tarihi ve Restorasyon Enstitüsü Bülteni, 1 (4), 59-61.

Taeschner, F. (2010). Osmanlı Kaynaklarına Göre Anadolu Yolları, Bilge Kültür Sanat Yayınevi, İstanbul.
Tekeli, i. (1994). The Development of the Istanbul Metropolitan Area: Urban Administration and Planning, IULA-EMME Yayını, İstanbul. 